\title{
PROGRAMME OF SESSIONS
}

\section{MONDAY 26 JULY 2004}

\section{Glacier and ice sheet hydrology}

H. Haidong: A simple method to estimate melting under surficial moraine

P. Clendon, W. Lawson, R. Sproken-Smith: Ablation of debris covered ice on the McMurdo Ice Shelf

R.R. Johnston, A.G. Fountain, T. Nylen: Channel development on Lower Taylor Glacier, McMurdo Dry Valleys, Antarctica

R.B. Alley, T.K. Dupont, B.R. Parizek: Possible role for surficial lakes in meltwater drainage from cold glaciers

M. Tranter, A.G. Fountain, W.B. Lyons, T. Nylen, K.A. Welch: The chemical composition of runoff from Canada Glacier, Antarctica

A.G. Fountain, R.B. Schlichting, R.W. Jacobel, P. Jansson: Flow through fractures, a new perspective on englacial hydrology

A.P. Ahlstrøm, J.J. Mohr, N. Reeh, E. Lintz Christensen, R. LeB. Hooke: Impact of enhanced surface melting on basal water pressure beneath the Greenland Ice Sheet margin

J.T. Harper, N.F. Humphrey, W.T. Pfeffer: Spring development of the subglacial hydrological system: observations from a glacier-scale network of borehole and surface instruments

E.V. Isenko, B.R. Mavlyudov, R. Naruse: Evolution of a glacial water channel: numerical approaches

G. Lappegard, J. Kohler: Determination of basal hydraulic systems based on subglacial high pressure pump experiments

T. Matsumoto: Changes in subglacial drainage systems of Koryto Glacier, Kamchatka Peninsula, Russia, inferred from features of suspended sediment and hydrochemistry

A. Braun, U.H. Fischer, A. Bauder, G.E. Flowers: Changes in geometry and subglacial drainage derived from digital elevation models: Unteraargletscher, Switzerland, 1927-1997

S.P. Carter, D.D. Blankenship, D.L. Morse, M.E. Peters: Evidence for subglacial waterways in the Concordia Valley, Antarctica

\section{TUESDAY 27 JULY 2004}

\section{Poster session}

D.R. Fatland, S. O'Neel, B. Grissom: Instrumentation and seismicity at the Columbia Glacier Calving Front

C.O. Mohrholz, M. Thoma, M.A. Lange, H. Sandheger, K. Grosfeld: Numerical modelling of Riiser-Larsen and Brunt Ice Shelves, Antarctica

D. MacAyeal, M. Okal: Basal melting rates of iceberg C16, Ross Sea, Antarctica

S. O'Neel, W.T. Pfeffer, R. Krimmel, M. Meier: A force balance analysis over the lower reaches of Columbia Glacier, Alaska during its rapid retreat

N. Young, D.R. MacAyeal: Case study of the October, 2003, break-up of iceberg B15A, Ross Sea

M.E. Peters, D.D. Blankenship, D.L. Morse: Radar sounding methods for characterizing subglacial interfaces of grounding zones and ice shelves

J. Weertman: Slip event propagation direction in transition region of low surface slope

M. Craven, F. Carsey, A. Behar, J. Matthews: In situ imagery of meteoritic ice-marine ice transition and marine ice-ocean interface on the Amery Ice Shelf

K. Satow, R. Naruse, E. Isenko, P. Skvarca: Measurements of calving activities at Glaciar Perito Moreno, Southern Patagonia

F. Pattyn, M. Nolan, B. Rabus, S. Takahashi: Localized basal motion of a polythermal arctic glacier: McCall Glacier, Alaska, USA

C.L. Hulbe, S. Quinn: Thermal cycles at the base of a floating ice mass driven by ice heat flow through the ice

B. Paschke, N. Blindow, M.A. Lange: Sensitivity studies on model modifications to assess the dynamics of the temperate ice cap on King George Island

W. Wang, H.J. Zwally: Estimating the basal melting/sliding of Chasma Boreale, North Polar Cap on Mars

J.M. Shea, S.J. Marshall, F.S. Anslow: Seasonal evolution of hydrometeorological relationships on the Haig Glacier, Canadian Rockies

V.M. Kotlyakov, N.I. Osokin, O.V. Rototaeva: Causes and consequences of the catastrophic surge of the Kolka glacier in the North Caucasus 2002

O. Nagornov, Y. Konovalov: Reconstruction of past temperatures for Arctic glaciers subjected to intense sub-surface melting

K. Matsuoka, T. Thorsteinsson, E.D. Waddington: Anisotropic radio-wave scattering from within temperate glacier ice, Mýrdalsjökull, Iceland

N. Rutter: Impact of subglacial hydrology on the release of water from temporary storage in an Alpine glacier

J.O. Naslund, P. Jansson, J.L. Fastook, J. Johnson: Modelling ice-sheet basal meltwater production using realistic geothermal heat-flow data

N.S. Eyre, A.J. Payne, D.J. Baldwin, H. Björnsson: The hydrological regime at Vestari-Hagafellsjökull, Iceland, as identified from borehole tracing

S. Lundstrom: Late Pleistocene subglacial (tunnel) channel formation during deglaciation of ice-sheets: was tunnel formation associated with freezing of supercooled meltwater?

K. Cozzetto, D. McKnight: Active layer dynamics in stream hyporheic zones, McMurdo Dry Valleys, Antarctica

J. Stroeve, A. Ahlstrom, A. Nolin: Albedo variability in the Jakobshavn Drainage Basin and surrounding area

A.J. Payne, J.L. Wadham, A.P. Wright, J. Kohler: Assessing the contribution of rainfall to the mass balance of Svalbard glaciers

A.F. Ebnet, A.G. Fountain, T. Nylen: A temperature index model of stream flow in Taylor Valley, Antarctica

J.V. Johnson: Estimating basal melt rates in Antarctica

A.G. Fountain, T.H. Nylen, R.R. Johnston, C.C. Delany: Spatial patterning of surface melt on the polar glaciers of Taylor Valley, Antarctica

B.H. Vaughn, A.G. Fountain: Stable isotopes and electrical conductivity as keys to understanding water pathways and storage in South Cascade Glacier, Washington

H. Henry: A study of the role of the firn pack in summer meltwater discharge from a temperate glacier

T.J. Fudge, J.T. Harper, N.F. Humphrey, W.T. Pfeffer: Time/space variability in diurnal borehole water levels, Bench Glacier, Alaska

L.E. Peters, S. Anandakrishnan, R.B. Alley, J.P. Winberry, D.D. Blankenship, D.L. Morse, A.M. Smith and E.C. King: Evidence for thick sedimentary strata overlain by a meters-thick dilatant subglacial till beneath a West Antarctic Ice Stream: observations and implications

M. Jeffries, K. Morris, C. Duguay: Ice growth and decay at shallow ponds in Central Alaska: II numerical modelling of contemporary processes, 1999-2003

K. Morris, M. Jeffries, C. Duguay: Ice growth and decay at shallow ponds in Central Alaska: III simulating past variability (1953-2000) and future climate change effects

M. Gould, M. Jeffries: Thermal regime of snow and ice on frozen ponds in Central Alaska

X. Ma, T. Yasunari, T. Ohata, Y. Fukushima: The influence of snowmelt and river ice on runoff of the Lena River

M.O. Jeffries, D. Norris-Tull, R. Reihl: The Alaska Lake Ice and Snow Observatory Network (ALISON): A university and K-12 science education partnership

D. Samyn, A. Svensson: Ice-fabric analyses in very fine-grained ice at least possible: an example from Antarctic cold basal ice

D. Notz, J.S. Wettlaufer, M.G. Worster: An in situ nondestructive method for measuring the salinity and solid fraction of impure ice

S. Hashimoto, S. Zhou, M. Nakawo, M. Shimzu, N. Ishikawa: Temporal isotope change in wet snow layers in association with mass exchange between snow particles

T. Tanaka, Y. Oda: Selective runoff of ion components in snow cover at Mt. Hyonosen in Sanin area, Japan

N. Osokin, R. Samoilov, A. Sosnovskiy: Mathematical modeling of heat and mass exchange in melting snow

P. Buzzini, B. Turchetti, G. Diolauiti, C. D'Agata, A. Martini, C. Smiraglia: Yeast biodiversity in melting ice from glaciers in the Italian Alps 
E. Forasacco, B. Leoni, G. Diolaiuti, M. Cotta Ramusino, C. Smiraglia: Study of the ecosystem of an alpine lake with calving phenomena: Miage Lake (Mont Blanc Group, Italian Alps)

I. Braslavsky, P. Conrad, K. Meiners, E. Thomson, J.S. Wettlaufer, L.A. Wilen: The interaction of biopolymers with the surface of ice

\section{Plenary lecture}

R.B. Waitt: The Missoula floods

\section{Glacier and ice sheet hydrology (cont.)}

M.J. Roberts, H. Björnsson, F. Pálsson, M.T. Guðmundsson: Ice-water interactions during floods from Graenalon glacier-dammed lake, Iceland

R. Motyka, D. Trabant, M. Truffer: Hubbard Glacier, Alaska: the 2002 closure of Russell Fjord and the potential for future closures based on glacier dynamics and fjord bathymetry

J. Box: Greenland ice sheet surface mass balance 1991-2000: application of Polar MM5 mesoscale model and in situ data

T.K. Dupont, R.B. Alley: Conditions for the reversal of ice/air surface slope on ice streams and shelves: a model study

T.T. Creyts, G.K.C. Clarke: Heat transfer from supercooled subglacial water

R. Lorrain, D. Samyn, R. Souchez: Basal ice formed by freezing of upward flowing pore-water indicated by its isotopic composition

M. Skidmore, A. Jackson, K. Grust, P. Nienow, M. Tranter: Seasonal suspended sediment dynamics at a polythermal outlet glacier of the Greenland Ice Sheet

M. Brugman: Summertime high water input events and impact on glacier stability

\section{WEDNESDAY 28 JULY 2004}

Excursion to Mt. Hood

Banquet and Seligman Crystal presentation (Edgefield Inn, Troutdale, OR)

\section{THURSDAY 29 JULY 2004}

\section{Plenary lecture}

C. McKay: Life and ice on earth and beyond

\section{Ice and ecology}

J.D. Barker, M.J. Sharp, R.J. Turner: Biogeochemical transformations of organic carbon in glacier systems

G. Royston-Bishop, J.C. Priscu, M. Tranter, B. Christner, M.J. Siegert, V. Lee: Incorporation of particulates into accreted ice above subglacial Lake Vostok, Antarctica

\section{Snow and water interactions}

I. Howat: Trends in California's spring snowpack over a half century of climate warming

H.-P. Marshall, G. Koh, R.R. Forster: Estimating alpine snowpack properties using FMCW radar

P.K. Srivastava: Variation in failure characteristics and microstructure of melt-freeze snow

C.E. Bøggild, N. Reeh: Melt water retention in a profile across the Greenland ice sheet

E.S. Cutler, B.B. Fitzharris: Surface snow melt at high elevation in the Southern Alps of New Zealand

\section{International Glaciological Society annual meeting}

\section{Physics of ice and water}

C. Bock, H. Eicken: Pore structure and permeability of Arctic sea ice

J. Neufeld, J.S. Wettlaufer: Flow-induced morphological instability in sea ice: theory and experiment

J.S. Wettlaufer, L. Benatov: Violent grain boundary melting

D. Samyn, A. Svensson, S. Fitzsimons, R. Lorrain: Enhanced deformation the base of cold Antarctic glaciers: the case of amber ice

A. Rempel: Englacial phase transformations driven by intergranular flow

A. Pralong, M. Funk, K. Hutter: Anisotropic damage mechanics for crevasse modeling

J.S. Walder, D.C. Trabant, A.G. Fountain, M. Cunico, S.P. Anderson, R.S. Anderson, A. Malm: Faulting and flow in an ice dam associated with annual filling and drainage of a glacier-dammed lake

\section{Lake and river ice}

M. Jeffries, K. Morris: Ice growth and decay at Shallow Ponds in Central Alaska: I observation and measurement, 1999-2004

S. Sleewaegen, S. Fitzsimons, M. Stievenard, R. Lorrain: Textural and isotopic evidence for the formation, in the glacier/lake contact zone, of the ice cover of an Antarctic proglacial lake

W.B. Lyons, R.A. Virginia, A.E. Carey, C. Tremper, B. Csatho, D.H. Wall: Groundwater seeps in Taylor Valley Antarctica: an example of a decadal subsurface melt event

\section{FRIDAY 30 JULY 2004}

\section{Calving glaciers and ice shelves}

W.T. Pfeffer: Tidewater instability and upglacier propagation of kinematic waves

F.M. Nick, J. Oerlemans: Dynamics of calving glaciers: a simple model applied to three temperate tidewater glaciers

D. Benn, G. Diolaiuti, M. Kirkbride, L. Nicholson, C. Smiraglia, C. Dogata and T. Carnielli: Calving processes in freshwater conditions: case study of Miage Glacier (Mont Blanc, Italian Alps)

K. Roehl: Thermal notch development at a freshwater-calving glacier

O. Sergienko, D.R. MacAyeal: Surface melting on the Larsen Ice Shelf

T.A. Scambos, C.L. Hulbe, M.A. Fahnestock: Catastrophic ice-shelf break-up in Antarctica

L. Padman, H.A. Fricker, M. King, S. Erofeeva: Tidal Influence on melt rates of Antarctic Peninsula Ice Shelves

M. Thoma, K. Grosfeld, M.A. Lange: Climate sensitivity of the Eastern Weddell ice shelf-ocean systems

H.A. Fricker, N.W. Young, J. Bassis, R. Coleman, J.-B. Minster: Observation of variable rift growth rates on the Amery Ice Shelf, East Antarctica

M.A. Lange, K. Grosfeld, H. Sandhager: On the role of ice shelf-ocean interaction for the Antarctic climate system

\section{Effect of water on ice flow}

A. Bauder, A. Bauder, D.M. Mickelson, S.J. Marshall: Numerical modeling investigations of the subglacial conditions of the southern Laurentide Ice Sheet M. Luethi, M. Funk, A Iken: Hydraulic conditions at the base of the ice sheet adjacent to Jakobshavn Isbrae, West Greenland

B.R. Parizek, R.B. Alley: Effects of increased surface melt on the dynamics of the Greenland ice sheet

F. Pattyn, S. De Brabander, A. Huyghe: Basal and thermal control mechanisms of East-Antarctic ice streams: Ragnhild vs Shirase

R.S. Anderson, S.P. Anderson, J.S. Walder, D.C. Trabant, A.G. Fountain: Kennicott Glacier dynamics: response to the hidden creek lake outburst flood

S. Sugiyama, R. Naruse, Y.D. Murav'ye: Surface strain anomaly induced by the drainage of englacial water in Koryto Glacier, Kamchatka, Russia

N.R. Iverson, D. Cohen: A laboratory device for study of glacier slip over hard and soft beds 